\title{
How does obesity lead to insulin resistance?
}

\section{Experiments on mice show that an enzyme called DNA methyltransferase $3 a$ is involved in insulin resistance via an epigenetic mechanism.}

CHAN HEE J CHOI AND PAUL COHEN

Related research article You $D$, Nilsson $E_{\text {, }}$ Tenen DE, Lyubetskaya A, Lo J, Jiang R, Deng J, Dawes BA, Vaag A, Ling C, Rosen ED, Kang S. 2017. Dnmt3a is an epigenetic mediator of adipose insulin resistance. eLife 6:e30766. DOI: 10.7554/eLife. 30766

I nsulin is a hormone produced by the pancreas that regulates the concentration of glucose in the blood (Saltiel and Kahn, 2001; Taniguchi et al., 2006). Following a meal, insulin secretion increases glucose uptake in muscle and fat, and reduces the production of glucose by the liver, enabling blood glucose levels to be maintained within a precise range. However, in cases of chronic overnutrition, the body can become less responsive to insulin, leading to a state known as insulin resistance. Initially, the pancreas responds by secreting more insulin, but when this can no longer compensate for the impaired insulin response of the liver and other organs, type 2 diabetes develops (Prentki and Nolan, 2006).

Insulin resistance serves as a key link between obesity and type 2 diabetes (Kahn and Flier, 2000), and understanding how obesity causes insulin resistance will improve our knowledge of type 2 diabetes and our ability to treat obesityrelated complications. It is likely that the development of obesity-induced insulin resistance involves a complex interplay of genetic and environmental factors (Samuel and Shulman, 2012).
One mechanism by which cells can integrate signals from the environment is through epigenetic changes: these are changes that modify DNA or the proteins that organize the DNA within cells without changing the underlying DNA sequence (Jaenisch and Bird, 2003). DNA methylation, for example, is an epigenetic change that involves adding a methyl group to a cytosine base that is upstream of guanosine. Islands of these $\mathrm{CpG}$ sequences are often found in the gene promoters near the start of genes, and the methylation of these bases usually reduces gene expression. Now, in eLife, Sona Kang, Evan Rosen and colleagues in the USA, Denmark and Sweden - including Dongjoo You of the University of California Berkeley as first author - report how a key epigenetic regulator called Dnmt3a contributes to obesity-related insulin resistance (You et al., 2017).

The DNA methyltransferase (Dnmt) family of enzymes catalyze the methylation of DNA (Denis et al., 2011). You et al. noticed that fat cells taken from obese mice contained high levels of two DNA methyltransferases, and experiments on fat cells grown in the laboratory suggested that one of these enzymes - Dnmt3a - had a role in the development of insulin resistance. When the researchers knocked down or inhibited Dnmt3a, the fat cells were able to take up more glucose in response to insulin, even when they had been treated with substances that induce insulin resistance. Similar results were observed in genetically engineered mice that lacked Dnmt3a in their fat cells. When placed on a high fat diet, the knockout mice gained the same amount of weight as wild-type 
mice, but they demonstrated improved glucose and insulin tolerance, and their fat cells responded more strongly to insulin.

You et al. then performed a screen to check if blocking or overexpressing Dnmt3a changed the level of transcription of various genes. They found that a gene called Fgf21, which encodes a secreted protein that helps fat cells to absorb glucose (Kharitonenkov et al., 2005), was transcribed less when Dnmt3a was overexpressed. Fgf21 is predominantly secreted by the liver, but fat cells are also known to express Fgf21. Based on their findings, You et al. suggest that Dnmt3a can induce insulin resistance in fat cells by methylating the $\mathrm{CpG}$ islands in the Fgf21 promoter region. This reduces the expression of Fgf21 genes, which in turn makes fat cells more resistant to insulin. Similar mechanisms might also be at play in human fat cells: people with diabetes had higher methylation levels near the FGF21 gene compared to people without diabetes, and the degree of methylation was also inversely correlated with the levels of FGF21 mRNA.

While insulin resistance may play a fundamental role in the development of type 2 diabetes in obese individuals, currently available anti-diabetic agents that target insulin resistance are limited to a single class of drugs called thiazolidinediones, which are no longer widely used due to potential side effects (Yki-Järvinen, 2004). DNA methylation has been an attractive therapeutic target in other clinical contexts, such as cancer. Therefore, targeting Dnmt3a or Fgf21 could provide new treatment opportunities for obesity-related complications such as insulin resistance.

You et al.'s study raises several key questions that could be addressed in future studies. First, the mechanism underlying the upregulation of Dnmt3a in obesity is not clear. Second, the repression of Fgf21 appears to explain only some of the downstream actions of Dnmt3a. Further research may be able to identify additional genes and pathways that are regulated by Dnmt3a, which could help with the development of alternative treatments for insulin resistance.

Chan Hee J Choi is in the Laboratory of Molecular Metabolism, The Rockefeller University, New York, United States

chc2056@med.cornell.edu

(iD) https://orcid.org/0000-0002-9892-9330
Paul Cohen is in the Laboratory of Molecular

Metabolism, The Rockefeller University, New York, United States

pcohen@mail.rockefeller.edu

(iD http://orcid.org/0000-0002-2786-8585

Competing interests: The authors declare that no competing interests exist.

Published 14 December 2017

\section{References}

Denis H, Ndlovu MN, Fuks F. 2011. Regulation of mammalian DNA methyltransferases: a route to new mechanisms. EMBO Reports 12:647-656. DOI: https:// doi.org/10.1038/embor.2011.110, PMID: 21660058 Jaenisch R, Bird A. 2003. Epigenetic regulation of gene expression: how the genome integrates intrinsic and environmental signals. Nature Genetics 33:245254. DOl: https://doi.org/10.1038/ng1089,

PMID: 12610534

Kahn BB, Flier JS. 2000. Obesity and insulin resistance. Journal of Clinical Investigation 106:473-481.

DOI: https://doi.org/10.1172/JCl10842, PMID: 10 953022

Kharitonenkov A, Shiyanova TL, Koester A, Ford AM, Micanovic R, Galbreath EJ, Sandusky GE, Hammond LJ, Moyers JS, Owens RA, Gromada J, Brozinick JT, Hawkins ED, Wroblewski VJ, Li DS, Mehrbod F, Jaskunas SR, Shanafelt AB. 2005. FGF-21 as a novel metabolic regulator. Journal of Clinical Investigation 115:1627-1635. DOI: https://doi.org/10.1172/ JCI23606, PMID: 15902306

Prentki M, Nolan CJ. 2006. Islet beta cell failure in type 2 diabetes. Journal of Clinical Investigation 116: 1802-1812. DOI: https://doi.org/10.1172/JCI29103, PMID: 16823478

Saltiel AR, Kahn CR. 2001. Insulin signalling and the regulation of glucose and lipid metabolism. Nature 414:799-806. DOl: https://doi.org/10.1038/414799a, PMID: 11742412

Samuel VT, Shulman GI. 2012. Mechanisms for insulin resistance: common threads and missing links. Cell 148:852-871. DOI: https://doi.org/10.1016/j.cell.2012. 02.017, PMID: 22385956

Taniguchi CM, Emanuelli B, Kahn CR. 2006. Critical nodes in signalling pathways: insights into insulin action. Nature Reviews Molecular Cell Biology 7:8596. DOI: https://doi.org/10.1038/nrm1837, PMID: 164 93415

Yki-Järvinen H. 2004. Thiazolidinediones. New England Journal of Medicine 351:1106-1118. DOI: https://doi.org/10.1056/NEJMra041001, PMID: 15356308

You D, Nilsson E, Tenen DE, Lyubetskaya A, Lo J, Jiang R, Deng J, Dawes BA, Vaag A, Ling C, Rosen ED, Kang S. 2017. Dnmt3a is an epigenetic mediator of adipose insulin resistance. eLife 6:e30766. DOI: https://doi.org/10.7554/eLife.30766, PMID: 290 91029 